\title{
Evaluation of risk factors for mortality and long- term survival after repair of acute type-A aortic dissection in 836 patients
}

\author{
B Tutkun*, S Buz, A Abd El Al, F Büttner, M Pasic, R Hammerschmidt, Y Weng, R Hetzer \\ From 23rd World Congress of the World Society of Cardio-Thoracic Surgeons \\ Split, Croatia. 12-15 September 2013
}

\section{Background}

This study was designed to explore predictive factors for mortality and long-term survival in patients with acute type-A aortic dissection. We retrospectively assessed our data over a 15-year period starting in 1996.

\section{Methods}

Between 01/1996 and 09/2011, 836 patients (559 men) with a mean age of $59.6 \pm 13.6$ (range 18-92) years underwent surgery for acute type-A aortic dissection. No patients were excluded from immediate operation irrespective of age and preoperative status unless uncontrollable hemorrhage and/or cardiac arrest occurred before the patient reached the operating room. Ninety-two perioperative variables were statistically analyzed to identify predictors for early mortality.

\section{Results}

The overall 30 -day mortality was $22.3 \%$ (without cardiogenic shock $18.4 \%$ ). The mortality rate was $9.8 \%$ in patients aged $<45$ years and $34.6 \%$ in older patients aged $\geq 80$ years. In the last 5 years the overall mortality was reduced to $17.7 \%$ (without cardiogenic shock $15.3 \%$ ). A multivariable logistic regression model showed that age $>60$ years (OR $1.03,95 \% \mathrm{CI}, 1.01$ to $1.04, \mathrm{P}<0.001)$, preoperative high inotropic score (OR 1.9, 95\% CI 1.1 to 3.0, $\mathrm{P}<0.001$ ), and additional CABG (OR 2.6, 95\% CI 1.6 to $4.1, \mathrm{P}<0.001$ ) were predictors of 30-day mortality.

The long-term survival and freedom from reoperation at 1,5 and 10 years were $70.5 \%, 58.5 \%, 42.1 \%$ and $96.4 \%$, $91.2 \%, 88.8 \%$, respectively.

* Correspondence: tutkun@dhzb.de

Cardiothoracic and Vascular Surgery, Deutsches Herzzentrum Berlin, Berlin, Germany

\section{BiolMed Central}

\section{Conclusions}

The results of this study support our institutional policy for acute type-A aortic dissection of not excluding any patients from the operation regardless of preoperative status and age.

Published: 11 September 2013

doi:10.1186/1749-8090-8-S1-O43

Cite this article as: Tutkun et al:: Evaluation of risk factors for mortality and long-term survival after repair of acute type-A aortic dissection in 836 patients. Journal of Cardiothoracic Surgery 2013 8(Suppl 1):O43.
Submit your next manuscript to BioMed Central and take full advantage of:

- Convenient online submission

- Thorough peer review

- No space constraints or color figure charges

- Immediate publication on acceptance

- Inclusion in PubMed, CAS, Scopus and Google Scholar

- Research which is freely available for redistribution
C Biomed Central 